\title{
Development of Ancient Athens Before Hellenistic Period
}

\author{
Juan Sergio Martinez Vazquez \\ Autonomous University of Carmen, MEXICO \\ Faculty of Educational Sciences, Campeche
}

Received 1 October 2019 - Revised 13 December 2019 • Accepted 15 December 2019

\begin{abstract}
This paper describes a brief overview of the history of ancient Athens, from the period of the first legislators to the Hellenistic period. One of the basic features that characterize this period is the continued presence of conflicts and hostilities between Athens and rival city-states, including those in present-day Greece, but also in Asia Minor and Southern Italy. Also, this period is followed by the continuing threatening and battles with the Persian Empire. It is a period of the history of Athens in which huge social development takes place, in all segments of social life. The various institutions of the state are established, and during this period, regardless of the presence of phases of tyranny as a form of government, the foundations of the democratic system, which exists in the modern world, are being created. Also, there has been an unprecedented period of development in history in the fields of philosophy, science, culture, art and social life in general.
\end{abstract}

Keywords: ancient Athens, democracy, legislative, Golden age, Peloponnesian war.

\section{Introduction}

In ancient times, Athens was ruled by kings, i.e. basileus ( $\beta a \sigma ı \lambda \varepsilon \dot{v} \varsigma$ ). Their rule was first restricted and then abolished by eupatrids. In order to justify it, the abolition of royal authority is shrouded in the veil of legend. The last Athenian king, Kodros, was killed in the war against the Dorians from the Peloponnese. Upon learning of the prophecy that the losing side of the king would win, he disguised himself as a lumberjack and went to the enemy camp. There he attacked Doric soldiers and heroically died in battle (What was democracy in ..., 2019). After his death, the Athenians no longer chose kings because there was no citizen worthy of succeeding him.

With the abolition of the monarchy, all power in the Athenian state passed into the hands of eupatrids. Nine archons were selected from their ranks. Their rule was initially lifelong and therefore similar to royalty. It is then restricted, first to ten and then to one year. The first among the archons was an archon-eponym who had administrative and judicial authority. The second was an archon-basileus who had religious authority, the third was an archon-polemarch who had military authority, and at the same time regulated relations with metics ( $\mu$ غ̇ंolкos, foreigners permanently resident in Athens, who were free but without political rights). The other six were archon-tesmotets who charged with maintaining and interpreting the laws and controlled the work of the other functionaries. The archons governed the Athenian state together with the

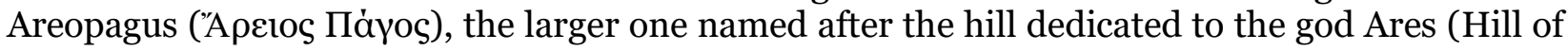
Ares), on which it sat. Former archons were entering the Areopagus. This council oversaw all state affairs and kept the laws of Athens. In Athens, as in Sparta, there was a national assembly - the

(C) Authors. Terms and conditions of Creative Commons Attribution 4.0 International (CC BY 4.0) apply. Correspondence: Juan Sergio Martinez Vazquez (PhD student), Autonomous University of Carmen, Faculty of Educational Sciences, Campeche, MEXICO. E-mail: jsmartinez93@gmail.com. 


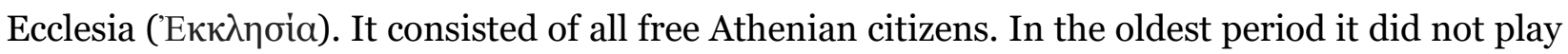
a significant role in the management of Athens.

Athenian social order was similar to that of most cities (polis) of the Hellenic world. Citizens were divided into aristocracy and demos, so aristocrats were people of noble descent. Their lineages were thought to be descended from Hellenic gods. The Athenians called them Eupatrids, meaning "born of noble fathers" (What was democracy in ..., 2019). They lived in Athens itself, or on large tracts of land in a fertile plain around the city. Demos, i.e. people, consisted of peasants, artisans and merchants. The peasants lived mostly in the interior of Attica, where they cultivated their land. Some of them have become so impoverished over time that they have been forced to cultivate the land of eupatrids, giving them one-sixth of the yield. As there was relatively little arable land in Attica, many citizens had to devote themselves to crafts and trade. They resided in smaller settlements along the banks of Attica and in Athens itself. In the city, for

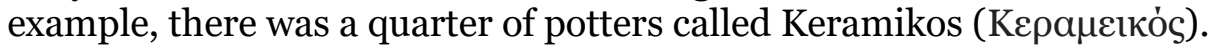

Every wealthier Athenian owned slaves. They were his property; he could sell, gift or free them, at his own request (Bitros \& Karayiannis, 2012). The position of the slaves varied and depended on the duties they performed. Most often they assisted in cultivating the land and raising livestock. Some worked as servants or doctors in the houses of their masters; those more educated reared their children. Some slaves ran craft workshops or trading shops for their masters. In the most difficult position were the slaves who worked in the mines. Every day, they were exposed to a life of danger, descending into the stuffy and dark mining shafts. Some slaves were turning millstones in the mills to grind grain. Debt slavery also existed in Athens: poor people borrowed from the rich; when they could not repay their debts, they fell into debt bondage with their family members.

\section{The first legislators}

Theseus first divided the inhabitants of the city into three classes: the rich and educated, the Eupatrids, the farmers and herders, the Geomorous, and the craftsmen, the Creators. By the time of the Dorian descent in Athens, it seems that the institution of kingship, which had been replaced by the aristocracy, had receded. Athens was ruled by a class of aristocrats known as the Eupatrids. Legislative power was exercised by a group of aristocrats, known as the Legislators (What was democracy in ..., 2019). The legislators in 624 BC. They commissioned the Drakon $(\Delta \rho \dot{\alpha} \kappa \omega v)$ to draft new legislation, which was also the first written legislation of ancient Athens. The Laws of the Drakon were only kept for thirty years because they were extremely harsh and eventually replaced by Solon's law in 594 BC. The period of aristocracy came to an end in 560

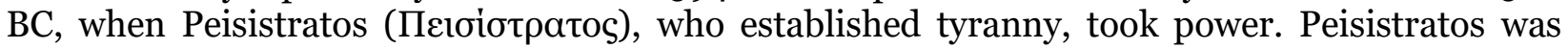
succeeded by the sons of Hippias and Hipparchus, who were the last tyrants of Athens. In 510 Tyranny was abolished and the legislator Cleisthenes laid the groundwork for Athenian democracy.

With the departure of tyranny from Athens, new political clashes arose between aristocracy and demos. The riot was ended by legislator Cleisthenes (K $\lambda \varepsilon \imath \sigma \theta \dot{\varepsilon} v \eta \varsigma)$. He divided the Athenian citizens into ten territorial branches (deme) (Pritchard, 2000). Each of these branches gave fifty representatives to the Chamber of five hundred, which replaced the Chamber of four hundred. Each deme had 500 representatives, and then a selection of 50 was made by throwing a dice. Cleisthenes is also prescribed the introduction of ostracism. This was initially a measure directed against people who wanted to restore tyranny in Athens, but it soon turned into a means of political calculation among the citizens (What was democracy in ..., 2019). Ecclesia was summoned for ostracism, and the vote was secret. The presence of 6,000 full-fledged Athenian citizens was necessary in order to be able to meet the ecclesiastics of ostracism. They were ostracized in exile for ten years, but did not lose property and civil rights. Some Athenians, though 
exiled for ten years, returned to this policy located in the Attica Peninsula before (this was the case with Aristides from whom the Athenians sought help), while others remained forever outside the policy of Athens (Themistocles, who was so disappointed that he was banished, that he crossed over to the Persian side).

\section{Persian wars}

The Persian wars were fought in the first half of the $5^{\text {th }}$ century BC between the Greeks and the Persians. These conflicts began with the conquest of Ionia by Cyrus II. The first phase of the wars, which was the cause of the subsequent conflicts, was the Ionian rebellion, which began after the failed siege of Naxos by the Persians.

After the Ionian rebellion, the Persian king Darius decided to avenge Athens and Eretria because they helped the Ionian cities. In 492 BC, Mardonius captured Thrace and Macedonia, but his fleet sank in Mount Athos. Two years later, Datis and Artafernes were able to conquer the Cyclades, Naxos and Eretria, but suffered a severe defeat at the Marathon. After Darius' death, Xerxes took over the leadership of the Persians, who attacked Greece in 480 BC in order to conquer it (Lazenby, 1993). Although initially his army had successes (Thermopylae, Artemisio), the Greeks succeeded in defeating the Persians in the battle of Salamis and the following year they defeated near Plateaus and Mycalis.

After the last two reported battles, the Greeks attacked Asia Minor. Then the Delian alliance was founded, which continued the war with the Persians for another thirty years. The Greeks fought the Persians in Thrace, Egypt, Asia Minor and Cyprus. After these conflicts, the Peace of Callias was signed, which meant the end of the wars and the victory of the Greeks.

In the first Persian campaign against Greece, organized by King Darius, the Persian fleet sailed against the two Greek cities that had assisted the Ionian cities during the Ionian rebellion, Eretria and Athens (Lazenby, 1993). After completely destroying Eretria, the Persian fleet headed for the Marathon. There, an Athenian force of 10,0oo men, with about 1,00o Plateans, led by Miltiades, awaited the Persian army. The Athenians without allies overwhelmed the Persian power and forced them to cancel their plans to occupy Greece prematurely.

Ten years later the successor of Darius Xerxes designed the same campaign. Most Greek cities in southern Greece allied to Xerxes. After failing to halt the Persian invasion of Thermopylae, the Greek army concentrated on the Corinthian isthmus while the fleet anchored in Salamis. The Persians reached undisturbed as far as Athens, which had been abandoned by its inhabitants, and caused huge disasters in the city. Shortly afterwards, however, the Persian fleet was destroyed in Salamis and the Persians withdrew from Attica. A year later the Persians lost the battle of Plataea and finally abandoned their plans to occupy Greece. There even Mardonius, although there were reactions from other Persian generals, believed that simply the numerical superiority of the Persians would not be enough to secure the victory. Mardonius was killed in the Battle of the Plateaus and his army was defeated.

\section{Prosperous period (Golden age)}

Shortly after the end of the Persian wars, the Pan-Hellenic alliance formed in 481 BC to confront the Persians broke up (Lazenby, 1993). The main reason was the continuation of the war against the Persians on the part of the Athenians, while the Peloponnesians did not wish to continue the war operations. So, when the Athenians sailed to Hellespont to liberate the Greek cities of the area, the Spartans with the rest of the Peloponnese left. Without the help of the rest of the Greeks, the Athenians went on a siege of Sistos and occupied it in $478 \mathrm{BC}$. In the same year, or perhaps a year later, in $477 \mathrm{BC}$. Athens established the Delian alliance or the first Athenian 
alliance. The organization of the alliance was undertaken by Aristides. With the founding of this alliance, the Athenians sealed their supremacy at sea.

After the Persian wars ended and the Persians left, Athens was a devastated city. During this period the construction of the city walls began. Sparta reacted to the construction of the walls and demanded from the Athenians not to fortify the city. Themistocles then went to Sparta to negotiate the matter, ordering the Athenians to continue building the walls. He delayed negotiations with the Spartans until the wall reached a height sufficient to repel the attacks, and then revealed to them that Athens had already been fortified.

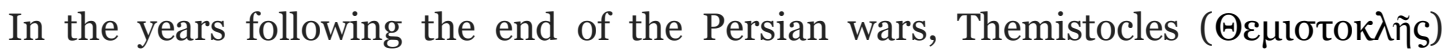
dominated the political scene in Athens. From 476 to 462, Kimon (Ki $\mu \omega v$ ) dominated the political scene of the city, which continued its war operations against the Persians. In 476 BC he occupied the city of Hion (Chrysopolis) at the mouth of the Strymon, which was still under Persian control. A year later, he attacked the Dolopes, pirates of Skyros, who defeated them by liberating the central Aegean from their action. The Dolopes were expelled from Skyros and Athenian clerics settled on the island.

The Athenians then carried out a series of operations aimed at strengthening the Delian alliance. They first occupied Karystos (473 BC) and then overthrew Naxos (469 BC) by returning the city to the alliance. The Delian alliance had begun to gradually become Athenian hegemony. In $467 \mathrm{BC}$ the Athenians and their allies again confronted the Persians who defeated the battle of the River Eurimedes on the coast of Lycia. With this victory of the Athenians the Persians abandoned their efforts to recover the Greek cities of Asia Minor. The first attempt to colonize Amphipolis by the Athenians confronted the Thassians. The Athenians finally conquered Thassos in $463 \mathrm{BC}$ and converted it into a taxable slavery.

Kimon's period ended in $462 \mathrm{BC}$ and a year later his ostracism followed. During this

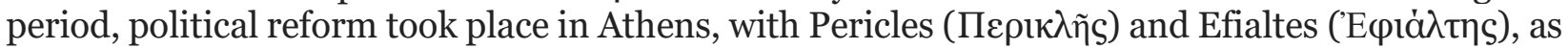
the pioneers. This reform removed many privileges from the Areopagus that were transferred to the Ecclesia of deme, the House of Pentecost (Parliament of 500 members) and Heliaia (Supreme Court). With these changes, the system became more democratic. From 461 BC Pericles dominates the political life of the city. The thirty years that followed until the outbreak of the Peloponnesian war were a period of great prosperity for Athens and became known as the golden age of Pericles. Pericles further strengthened the democratic character of the state by taking a series of prodemocracy measures. He established a salary for the citizens who participated in the Heliaia or the House of Pentecost in order to gain the opportunity to poorer Athenians to join the two institutions, who had not until then had the opportunity to temporarily quit their jobs and be elected to some office. The couple of institutions was also granted the right to elect nine archons.

In the military sector in $459 \mathrm{BC}$. Athens secured the Alliance with Megara and gained access to the Corinthian gulf. The Long walls were also built during this period (Camp, 2004). The development of Athens and the Corinthian gulf worried Corinth, which, by securing Aegina's alliance, undertook war operations against the Athenians. In $458 \mathrm{BC}$ the two opposing forces clashed in the city of Halia in southern Argolis with the Corinthians and Aeginites overpowering. Shortly after, however, the Athenians besieged Aegina and occupied it, forcing it to join the Delian alliance. The following year (457 BC) Sparta took action against Athens, which managed to ally itself with the Boeotians. Then began a long-standing dispute between the Athenians and the Spartans, often referred to as the first Peloponnesian war. In the first year the two opposing coalitions clashed in Tanagra with the Peloponnese and the Boeotians over the Athenians but a few days later the Athenians led by Myronides defeated their opponents at Oinofyta. With the victory of the Athenians in the battle of the Oinofyta, Boeotia temporarily passed into their control. Athens then made aggressive moves against Sparta. Under the command of the fleet by Tolmidis and then Pericles himself, the Athenians destroyed Gytheio and secured the alliance of Zakynthos, 
Kefalonia and Akarnania (Herodotus, 1998). The Athenians also carried out a second operation in Egypt during this period, assisting the local archon who had rebelled against the Persians. The operation failed, causing financial and military losses to Athenians. This forced them to terminate their operations against Sparta by declaring a ceasefire. At the same time, they ended peace with the Persians, known as the Peace of Callias by the name of the Athenian negotiator.

In $447 \mathrm{BC}$ the Thebans expelled the pro-Athenian group of the cities. The Athenians campaigned against them and defeated them in the battle of Chaeronea. After this failure, Athens lost control of Boeotia, which it had secured ten years earlier, at the Battle of the Oinofyta. A year later, Megara also withdrew from the Athenian alliance. Attempting to recover Megara led to a new conflict with Sparta. Eventually the Spartans and the Athenians decided to establish peace for thirty years and maintain the status quo before Megara's accession to Athens, that is, before 459 BC. The peace agreement is referred to as the Thirty years war (446 BC).

In the period after thirty years of peace Athens reached its peak. He founded the Thurian colonies (444 BC) in Greater Greece and Amphipolis (437 BC) in Macedonia, while forming an alliance with Rigios, and the Leontines in Greater Greece and Sicily. The development of Athens in the west again led her into a fierce rivalry with Corinth. The hatred of the Corinthians and their close allies of the Megara led to the implementation of the Megarian decree banning the Megara from using the ports of the Athenian alliance. A year later the Athenians reinforced Corfu in the war against Corinth. The Corinthians then incited their former colony Potidaea to revolt and leave the Delian alliance. The Athenians soon after sent an army to suppress the rebellion, which triggered the Peloponnesian war.

\section{Peloponnesian war}

The Peloponnesian war broke out in 431 BC. During the first period called the Archidamus' war the Spartans invaded and camped in Attica every year, while the Athenians closed the Long Walls and undertook operations with their fleet (Herodotus, 1998). In the second year, a terrible plague broke out in Athens that led to the death of two-thirds of the city's population. A year later, in 429 BC. Pericles saw his two sons, Paralos and Xanthippos, die from the terrible plague that struck the city. He himself died of the plague in August 429 BC. His successors succeeded Cleon $(\mathrm{K} \lambda \dot{\varepsilon} \omega \mathrm{v})$ in the following years. The most important activity of the Athenians in the following years was the capture of Pylos, which took place in $425 \mathrm{BC}$ and their victory over the Spartans in the battle of Sphacteria. The Athenians led by Demosthenes $(\Delta \eta \mu$ o $\theta \dot{\varepsilon} v \eta \mathrm{s})$ had captured and fortified Pylos. After this operation the Spartans departed from Attica and sent an army to the area, which was fortified on the island of Sphacteria. The Athenians then sent reinforcements led by Cleon, and in the ensuing battle on the island the Athenians succeeded in defeating the Spartans and capturing them, achieving their first major victory in the war.

One year after the success of Pylos, the Athenians turned against the Boeotians who defeated them in the battle of Delion. Conflicts then shifted to Halkidiki, where new cities had been moved by Sparta. The Athenians occupied Skionis and Mendis and then turned to their former Amphipolis colony, which had also left. The city was defended by the Spartans led by Brasidas. In the ensuing battle the Athenians were defeated, while Cleon and Brasidas were killed. Cleon was succeeded by his political opponent, Nicias. A year later, the Athenians and the Spartans seized peace known as the Nicias' peace, by the name of the Athenian leader who participated in the negotiations.

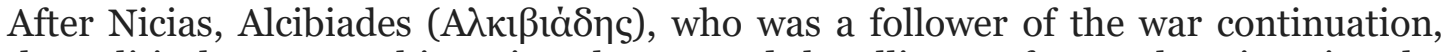
dominated the political scene. By his actions he secured the alliance of Argos by triggering the immediate intervention of Sparta that resulted in the battle of Mantinea (Herodotus, 1998). In this 
battle the Spartans prevailed, breaking up the Athenian alliance with Argos. In 416 BC the Athenians decided to relocate to Sicily, as they were attracted to the island's wealth and were always concerned about the empowerment of Syracuse, a city friendly to the Peloponnese, which was able to provide them with food and supplies. Already in $427 \mathrm{BC}$ they had sent a small force to help Rigio (today Reggio di Calabria) and the Leontines (today Lentini) who were threatened by Syracuse. In $416 \mathrm{BC}$ the reason was given when the city of Eigesta (Segesta) sought the help of Athens to protect itself from the attacks of neighboring Selinunte, which was an allied city with Syracuse. At the instigation of Alcibiades, they organized a very costly campaign, known as the Sicilian campaign, which was undertaken by the leaders Alcibiades, Lamachos and Nicias. Shortly after the departure of the mission, in the spring of 415 BC, Alcibiades was accused of a sacred act, the decapitation of Hermes, which had taken place in Athens shortly before the fleet's departure. The Athenians summoned Alcibiades to try him, but he escaped to Sparta. To avenge the Athenians, he advised the Spartans to send aid to Syracuse and fortify Dekeleia in Attica. The Spartans followed Alcibiades' advice and sent aid to Syracuse led by Gillippos. He forced the Athenians to abolish the siege of the city. In spite of the large fortifications sent by the Athenians under the command of Demosthenes and Eurimedes, the Athenian fleet and the army were defeated by the Syracuseans and Peloponnesians, suffering great turmoil. About 7,0oo Athenians and allies were captured and transported for forced labor to the Syracuse quarries.

Following the unfortunate outcome of the Sicilian campaign for the Athenians, the Peloponnesian war was rekindled. The Spartans, fortified at Dekeleia as Alcibiades had advised, severely harassed the Athenian countryside while the Athenians again fled into the Long walls (Herodotus, 1998). Apart from Sparta, they had to face the Ionian cities that were expanding. Chios gradually disbanded the Klazomenai, Eritrea and Miletus forcing the Athenians to send a fleet to bring them back to the Athenian alliance. Using Samos as their loyal base, they reinstated the above cities to the alliance. In $411 \mathrm{BC}$ there was an attempt in Athens to change the regime, by a group of oligarchs with their leaders, Phrynichus and Antifontas. The power temporarily fell to a body of 400 oligarchs overthrown that year. The fleet, which was in Samos at the time, retained leaders of the democratic line-up and recalled Alcibiades. Alcibiades assumed command of the Athenians in the siege of Kyzikos, where the Athenians defeated the Spartans by destroying their fleet. In the following years, the Athenian fleet continued operations in the wider area of Propontis, occupying Byzantium and Abdera. After these successes, Alcibiades was admitted to Athens, relieved of the accusations against him, and elected a new Athenian general (407 BC). He was defeated in the naval battle in the South and was deposed. Conon, who succeeded in defeating the Spartans in the battle of Arginus, took over as captain in the summer of 406 BC. Despite the victory of the Athenians, they condemned to death the generals who were held responsible for not collecting the corpses of the dead. A total of six generals were sentenced to death. The following year, the Spartans occupied Lampsacus, forcing the Athenians to send a fleet against them. After a year of siege Athens surrendered and the Peloponnesian war ended.

\section{Recovery of the city}

After the surrender of Athens, Sparta imposed an oligarchic regime on the city. Thirty oligarchs known as the Thirty tyrants came to power (Herodotus, 1998). Ten of them belonged to the oligarchic class of Critias (Kpıtias) and the other ten belonged to the oligarchic class of

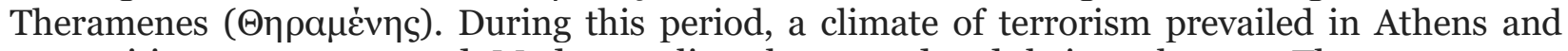
many citizens were executed. Moderate oligarchs reacted and their spokesman Theramenes was executed. Eventually Thrasivoulos was overthrown by the cruel regime of the thirty tyrants, a year later (403 BC) with 70 comrades occupying the fortress of Phylis and then with the support of more democrats occupying Piraeus. The oligarchs clashed with the democrats in Piraeus where they lost. Critias was also killed in this conflict. The oligarchs then fled to Eleusis where they remained until they were granted asylum by the new Athens regime. 
In the following years the Athenians allied themselves with the Boeotians, taking advantage of the latter attitude towards Sparta. In 395 BC Sparta sent an army against them, on the occasion of the intervention of the Boeots in Fokida. The two opponents clashed in Aliartos, where the Boeotians prevailed with their Athenian allies. The defeat of Sparta prompted other unhappy cities to turn against it, resulting in the creation of a large coalition of cities that now turned against Sparta. The result of the new situation was the outbreak of the Corinthian war that lasted nine years. The Spartans dominated the coalition at the Battle of Nemea just outside Corinth and at the Battle of Chaeronea but were defeated at sea, in the area of Knidos, by the fleet of Conon, reinforced by the Persians. In the following period, Sparta repeatedly raided Corinth, plundering the area. The Corinthians were supported by the Athenians under the leadership of Iphicrates and then by Chabrias. At the same time, the war continued in the sea where the Athenians were able to win back older allies, such as Lesbos, Samothrace and Thrace. The war caused great damage to both sides and led the warring parties to desire peace. As a result, they finally accepted a plan proposed by the Persian King of Artaxerxes. Under the peace agreement known as the Peace of Antalcidas, the Persians regained control of Asia Minor and Cyprus, while the Athenians retained the islands of Skyros, Lemnos and Imbros.

In $378 \mathrm{BC}$ Athens founded the second Athenian alliance with the aim of preventing Spartan expansion into the Aegean islands (Herodotus, 1998). The alliance was joined by most of the Aegean islands, Euboea, Halkidiki, the cities of the southern coasts of Thrace and later the Ionian islands except Zakynthos. In 371 BC Athens worried about strengthening Thebes closed peace with Sparta. Thebans after their win in the Battle of Leuctra in 371 BC they dominated Greece in the next period. Eventually they clashed with their opponents in Mantineia with the Athenians fighting alongside the Spartans. The Battle of Mantineia did not prove to be a winner but led to a peace treaty between the opposing sides. Athens, meanwhile, was trying to maintain the cohesion of the second Athenian alliance that was facing repeated attempts by cities to defect. Commanding the fleet chiefs, Iphikrates, Havria, Timotheus and Haris sought to maintain the integrity of the alliance. Between 357 and 355 a coalition of cities that had fled the alliance, with Rhodes, Kos and Chios, clashed with Athens. During the Allied war, as the war between the former members of the second Athenian alliance became known, the Athenians failed to bring the above cities back into the Alliance. During this period the third war broke out, in which the Athenians sided with the Phocians. This attitude confronted them with the Macedonians of Philip who had hastened to confront the Phocians. The Macedonians finally prevailed and made peace with the Athenians, the so-called Philocratic peace (346 BC). The Athenians, however, drifted away from Demosthenes' reasons, quickly abandoned the friendly attitude towards the Macedonians and began to form a coalition against them. The Thebans, Corinthians and Megara joined the coalition. The two adversaries clashed in Chaeronea in $338 \mathrm{BC}$, and in the ensuing battle the Macedonians who became the dominant force in the Greek territory prevailed.

\section{Conclusion}

The period described above represented a key period in the development of the ancient Athens, as a city-state. A few lines in this development are noticeable. Athens has strengthened economically, based on the development of the trade and maritime sectors, before all. Along with economic development, social development took place through the establishment of various state institutions. Notwithstanding the fact that in the described period of the history of Athens there were also tyrannies, as a form of government, the foundations of the democratic doctrine that exists today, were formed precisely during this period of Athens' development. Also, economic and social development was accompanied by uplift in all key areas of social life (culture, art, philosophy, science, sports, etc.). 


\section{Acknowledgements}

This research did not receive any specific grant from funding agencies in the public commercial, or not-for-profit sectors.

The author declares no competing interests.

\section{References}

Bitros, G. C., \& Karayiannis, A. D. (2012). The City-State of ancient Athens as a prototype for an entrepreneurial and managerial society. In: G. P. Prastacos et al. (Eds.), Leadership through the Classics. Berlin, Heidelberg: Springer-Verlag.

Camp, J. (2004). The archaeology of Athens. Yale University Press.

Herodotus (1998). The histories (Transl. R. Waterfield). Oxford University Press.

Lazenby, J. F. (1993). The defence of Greece 490-479 BC. Aris \& Phillips Ltd.

Pritchard, D. (2000). Tribal participation and solidarity in fifth-century Athens: A summary. Ancient History, 3O(2), 104-118.

... What was democracy in Ancient Athens? (2019). Retrieved 12 October 2019, from

http://www.nelson.com/albertasocialstudies/productinfo/gr6 9/docs/abss6ch3.pdf. 